\title{
Urgensi analisis kebijakan
}

\author{
Ulandari Safitri $^{\left.{ }^{*}\right)}$, Adek Nuarizal ${ }^{1}$, Nurhizrah Gistituati ${ }^{1}$ \\ ${ }^{1}$ Universitas Negeri Padang, Indonesia
}

\begin{tabular}{l} 
Article Info \\
\hline Article history: \\
Received Apr $03^{\text {rd }}, 2021$ \\
Revised May $09^{\text {th }}, 2021$ \\
Accepted Jun $09^{\text {th }}, 2021$ \\
\hline
\end{tabular}

\section{Keyword:}

Urgensi

Analisis

Kebijakan

\begin{abstract}
Analisis kebijakan merupakan sebuah ilmu sosial terapan yang menggunakan berbagai teknik dan metode dalam melahirkan informasi-informasi yang berhubungan dengan kebijakan. Analisis kebijakan bukan lah hal yang bersifat wajib namun memiliki dampak yang baik terhadap lahirnya keputusan. Namun banyak pemimpin yang tidak mengetahui bahwa pentingnya dilakukan analisis kebijakan. Tujuan penulisan artikel ini adalah untuk menyajikan informasi mengenai pentingnya analisis kebijakan. Metodologi penulisan ini menggunakan metodologi studi kepustakaan. Penulisan artikel ini dilakukan dengan mengkaji sebanyak 24 jurnal nasional yang berhubungan dengan analisis kebijakan yang terdapat pada data base google scholar. Hasil dari pengkajian kemudian di jabarkan melalui artikel ilmiah. Analisis kebijakan ini sangat penting untuk dilaksanakan. Alasan yang mendasari diperlukannya analisis kebijakan yaitu untuk mengetahui segala bentuk kelayakan dan pembiayaan dari kebijakan yang diambil yang dianalisis melalui proses ilmiah dengan pendekatan saintifik.
\end{abstract}

(C) 2021 The Authors. Published by IICET.

This is an open access article under the CC BY-NC-SA license (https://creativecommons.org/licenses/by-nc-sa/4.0)

\section{Corresponding Author:}

Ulandari Safitri

Universitas Negeri Padang

Email: ulandarisafitri30@gmail.com

\section{Pendahuluan}

Penyelenggaraan pendidikan di Indonesia berazaskan good governance (Hayati, 2014) . Azas ini semakin kuat untuk diaplikasikan pada tahun 1998 pasca bergulirnya reformasi. Pola kebijakan pendidikan lama lebih menekankan pengaturan pendidikan oleh pemerintah pusat yang mengakibatkan lemahnya aktualisasi penyempurnaan kapasistas pendidikan karena perlunya pemusatan yang dilakukan oleh pemerintah pusat (Suti, 2011). Sedangkan proses penyelenggaraan pendidikan dengan azas good governance ini lebih menekankan kepada akuntabilitas publik dalam porses pelaksanaan pendidikan (Prabowo et al, 2014).

Pada hakikatnya, konseptual kebijakan tersebut membawa harapan yang baik serta optimistik untuk memajukan dan meningkatkan sistem pendidikan di Indonesia (Rusydi, 2014). Namun ada beberapa hal yang perlu di maknai, hal tersebut berhubungan dengan pengaruh dari perubahan kebijakan yang meninggalkan persoalan yang berhubungan dengan manejeman, struktur organisasi, rekuitmen dan berhubungan dengan sistem keuangan.

Permasalahan tersebut timbul dikarenakan kurang tepatnya perumusan kebijakan yang dilakukan (Nugraha et al, 2021). Hal ini sesuai dengan pendapat yang disampaikan oleh Grindle (2004) yang menyatakan bahwa yang lebih penting dalam hal proses implementasi adalah fakta bahwa keputusan yang dibuat pada tahap desain atau formulasi memiliki dampak yang cukup besar pada bagaimana implementasi berlangsung. Dalam merumuskan sebuah kebijakan diperlukannya penetapan batas kebijakan yang 
berhubungan dengan anggaran, kelembagaan, kemampuan SDM, dan waktu (Pratiwi, 2016). Namun hal yang diingat bahwa sebuah kebijakan yang telah dirumuskan kemudian disahkan bukan berarti bahwa kebijakan tersebut terlepas dari berbagai masalah.

Analisis terhadap sebuah kebijakan sangat diperlukan agar memperoleh informasi yang diperlukan untuk merumuskan kebijakan yang mumpuni (Wibowo, 2013). Hal ini sesuai dengan pendapat Kerr yang menyatakan bahwa deskripsi tentang bagaimana kebijakan dibuat dapat memberi kita informasi yang diperlukan untuk membuat keputusan yang baik tentang hal-hal yang harus kita lakukan ketika membuat kebijakan (Hanisy, 2013). Dengan kata lain, deskripsi proses merupakan bagian dari deskripsi perilaku yang meskipun tidak dapat merekomendasikan tindakan tetapi dapat memberikan informasi yang penting untuk datang ke keputusan yang cermat tentang bagaimana kebijakan harus dibuat. Pernyataan tersebut menyatakan bahwa sebuah kebijakan sangat bermanfaat untuk menyajikan berbagai informasi untuk menyusun kebijakan sebelum kebijakan tersebut di rumuskan.

Kajian dalam merumuskan dan menganalisis kebijakan merupakan bagian dari perilaku pengambilan keputusan (Bawono, 2011). Penganalisisan kebijakan tidak mampu memberikan saran terhadap sebuah tindakan yang dilakukan namun penganalisisan ini dapat menyajikan informasi yang bersifat penting dalam merumuskan keputusan agar sebiah kebijakan dapat ditetapkan (Kiwang et al, 2015). Kebijakan merupakakan bagian dari politik yang ditetapkan oleh penyelengara negara untuk mengerjakan maupun tidak mengerjakan sesuatu (Syahwalan, 2019). Salah satu bentuk kebijakan yang sangaat erat berhubungan dengan pemerintahan adalah kebijakan pendidikan (Saifudin, 2015).

Kebijakan pendidikan merupakan pedoman yang berbentuk perangkat-perangkat yang dikembangkan oleh pemerintah untuk mengambil dan melaksanakan keputusan (Fernandes, 2018). Kebijakan pendidikan merupakan rangkaian keputusan dan tindakan yang mempunyai tujuan untuk memecahkan permasalahan yang berhubungan dengan sistem pendidikan serta memiliki dampak yang banyak terhadap warga negara (Nurhadjadmo, 2008). Maka oleh sebab itu kebijakan pendidikan harus dimaknai dan dianalisis secara maksimal agar kebijakan pendidikan tersebut memiliki dampak yang baik dan mengurangi resiko yang terjadi. Analisis kepentingan kebijakan pendidikan ini sangat penting dilaksanakan agar perumusan kebijakan dan pengambilan keputusan tepat untuk dilakukan. Berdasarkan kajian literatur yang penulis lakukan belum ditemukaanya bahasan khusus mengenai pentingnya analisis kebijakan. Banyak ditemukan tulisan mengenai konsep dasar kebijakan. Oleh sebab itu maka penulis ingin menyajikan informasi mengenai pentingnya analisis kebijakan.

\section{Metode}

Metodologi penulisan ini menggunakan metodologi studi kepustakaan. Penulisan artikel ini dilakukan dengan mengkaji sebanyak 24 jurnal nasional yang berhubungan dengan analisis kebijakan. Jurnal tersebut merupakan jurnal nasional yang berada pada data base google scholar. Hasil dari pengkajian kemudian di jabarkan melalui artikel ilmiah.

\section{Hasil dan Pembahasan}

\section{Pengertian Analisis Kebijakan}

Sebuah kebijakan sangat berhubungan dengan pengaturan agenda yang mengkaji persoalan-persoalan dan dibentuk dalam pengaturan intitusional yang berhubungan dengan proses organisasi serta saling berinteraksi dalam menanggapi hal-hal yang berhubungan dengan isu politik maupun dengan hal-hal yang bukan berhubungan dengan isu non politik (Narita, 2012). Analisis kebijakan merupakan aktivitas praktisi dan intelektual yang ditujukan untuk menghasilkan secara cermat, kritis dan mengkomunikasikan pengetahuan terhadap proses kebijakan yang dilaksanakan. Analisis kebijakan dapat diartikan sebagai sebuah ilmu yang menggunakan berbagai bentuk pengkajian dalam hal argumentasi dan diskusi politik untuk menghasilkan, melakukan penilaian secara kritis dan menyampaikan pengethauan yang berhubungan dengan kebijakan tersebut (Herdiana, 2018). Analisis kebijakan merupakan sebuah ilmu terapan yang bertujuan untuk merekomendasikan pemecahan masalah publik kepada public policy maker(Asmara, 2016). Pada kegiatan analisis kebijakan terdapat berbagai informasi yang berhubungan dengan permasalah kebijkan publik serta pendapat-pendapat mengenai kebijakan yang dapat dijadikan sebagai bahan dalam membuat kebijakan.

Analisis kebijakan dalam arti luas dimaknai sebagai bentuk penelitian terapan yang bertujuan untuk mendapatkan informasi mengenai permasalahan yang dihadapi agar menemukan solusi permasalahan yang tepat (Retnoningsih dan Marom, 2017). Pada era sekarang dengan bantuan ilmu modren berbasis teknologi dapat dijadikan sebagai alat dalam memecahkan permasalahan. Selain itu dengan bantuan teknologi modren 
juga mempermudah dalam mengamati langkah-langkah, menyusun informasi, penemuan bukti-bukti dan menemukan dampak penerapaan analisis kebijkan yang akan membantu para pembuat kebijakan dalam menentukan tindakan yang memiliki keuntungan dalam menganalis kebijakan. Didalam analisis kebijakan terdapat analisis biaya berupa analisis efektifitas biaya, analisis sistem biaya dan manfaatnya, dan analisis opertion riset. Namun disamping itu hal yang sangat diperhitungkan dalam analisis kebijakan adalah menganalisis kesulitan dan kendala lembaga yang berkaitan dengan keputusan publik dan proses penerapannya.

Melakukan analisis kebijakan publik tidak hanya saja sekedar melakukan pengamatan kebijakan dengan cara mengamati komponen-komponen yang ada didalamnya namun perlu juga proses pendesainan dan pensintesisan alternatif-alternatif yang memungkin ada dan timbul dari kebijakan tersebut. Kegiatan tersebut dapat dikembangkan melalui proses penelitian berupa pemberian penjelasan atau pandangan atas permasalahan yang akan diantisipasi sehingga berlakulah penelitian evaluasi. Hal ini selaras dengan pernyataan William N Dunn yang menyatakan bahwa analisis kebijakan merupakan disiplin ilmu sosial yang bersifat terapan dengan menggunakan berbagai jenis argumen dan metodologi penelitian agar memperoleh informasi yang berkaitan dengan pemecahan masalah kebijakan (Iqbal, 2015).

Weimer dan Vining menyatakan bahwa analisis kebijakan bukanlah sebuah keputusan. Weimer dan Vining menyatakan bahwa analisis kebijakan di definisikan sebagai sebuah saran maupun nasehat yang dijadikan sebagai pertimbangan bagi pembuat kebijakan sehingga pembuat kebijakan mendapatkan informasi mengenai masalah-masalah yang dihadapi (Hanisy, 2013). Selain itu nasehat tersebut beriisikan tugas-tugas yang harus dilaksanakan oleh pembuat kebijakan yang penerapannya berhubungan dengan masalah tersebut. Selain itu juga berisikan alternatif-alternatif kebijakan lainnya yang dapat dijadikan cadangan dalam pelaksanaan kebijakan.

Maka dari banyak pendapat tersebut dapat disimpulkan bahwa analisis kebijakan merupakan sebuah ilmu sosial terapan yang menggunakan berbagai teknik dan metode dalam melahirkan informasi-informasi yang berhubungan dengan kebijakan. Analisis kebijakan ini sangat penting untuk dilaksanakan apalagi dalam proses pendidikan. Maka untuk mengetahui seberapa penting analisis kebijakan ini dapat dilihat pada pemaparan selanjutnya.

\section{Urgensi Analisis Kebijakan}

Pelaksanaan analisis kebijakan sangat perlu dilaksanakan dikarenakan dapat membantu pembuat keputusan untuk mendapatkan informasi yang berhubungan dengan keputusan yang akan dibuat. Kegiatan analisis kebijakan tersebut dapat dilakukan melalui penelitian, mengklarifikasi dan memisahkan permasalahan yang dapat menemukan ketidaksesuaiakan antara tujuan dan upaya, menyajikan alternatif baru, serta mengusulkan cara untuk menyampaikan ide dalam perumusan kebijakan tersebut. Kontribusi utama dari proses pelaksanaan analisis kebijakan ini adalah untuk memberikan saran yang berhubunngan dengan keputusan dengan melakukan perhitungan kepekaan dan keutamaan parameter yang telah ditetapkan. Analisis kebijakan bukan lah hal yang utama dalam proses pengambilan kepentingan namun menjadi hal penting dikarenakan merupakan bagian dari proses penilaian lembaga tersebut.

Badjuri dan Yuwono menyatakan ada 5 point utama mengapa analisis kebijakan tersebut penting untu dilaksanakan: 1) Analisis kebijakan dilakukan melalui metode ilmiah yang bersifat obyektif, rasional dan saintifik. Hal ini mengisyaratkan apabila dilakukannya analisis kebijakan maka pembuatan kebijakan tersebut dilakukan secara ilmiah sehingga kebijakan tersebut dapat terukur dan dapat dipertanggungjawabkan; 2) Analisis kebijakan yang dilakukan dengan sungguh-sungguh dan bersifat komprehensif akan menghasilkan sebuah kebijakan yang tepat sasaran sehingga dapat meningkatkan kesejahteraan warga (public welfare); 3) Analisis kebijakan merupakan hal yang bersifat multidimensioanl, interdependent (saling berkaitan), dan berkorelasi antara satu dengan yang lainnya sehingga menjadi sangat penting untuk dilaksanakan agar menghasilkan pengaruh yang menyeluruh; 4) Analisis kebijakan dapat menghasilkan panduan secara menyeluruh untuk melaksanakan kebijakan dan melakukan penilaian. Fakta ini dikarenakan analisis kebijakan dapat bersifat substansial dan strategik sehingga dapat digunakan pada masa yang akan datang; 5) Analisis kebijakan juga dapat memberikan kesempatan besar bagi masyarakat untuk berpartisipasi dalam melahirkan kebijakan (public partisipation). Hal ini dikarenakan pada proses analisis kebijakan masyarakat dapat dijadaikan sebagai objek yang digunakan untuk menjalin aspirasi (Dengah et al, 2017)

Analisis kebijakan bermanfaat untuk menghindari adanya sebuah kebijakan yang diambil melalui pertimbangan yang gegabah atau pertimbangan yang dilandaskan oleh kekuasaan semata. Pertimbangan yang dilakukan secara ilmiah dengan pendekatan saintifik, obyektif dan rasional terkadang sulit untuk ditemukan (Tressa, 2015). Hal ini dikarenakan adanya korelasi pembuatan kebijakan dengan aspek politicking yang 
berhubungan dengan antara kebijakan pusat dan daerah. Maka disinilah pentingnya analisis kebijakan dilakukan. Dengan adanya analisis kebijakan yang dilakukan diharapkan mampu menghindari permasalahan yang bersifat politik dikarenakan analisis yang dilakukan dapat menyajikan informasi dan argumen secara menyeluruh sehingga dapat diterima oleh masyarakat.

Kunci utama yang dapat dilakukan dalam analisis kebijakan yaitu perlu nya pengidentifikasian masalah dan tujuan dirumuskanya kebijakan (Ismail, 2016). Namun banyak permasalahan yang sering terjadi adalah ketika penentu kebijakan memerintahkan analisis kebijakan untuk melakukan analisis namun tidak disertai dengan ketegasan informasi dan bahkan ada yang memberikan informasi dengan tujuan yang berbeda kepada penganalisis kebijakan.

Meskipun terdapat tujuan yang berbeda namun tujuan tersebut harus dicapai . Bisa jadi tujuan tersebut dapat dicapai dalam waktu dekat dan ada juga tujuan yang dicapai untuk generasi selanjutnya. Contoh yang dapat ditemua adalah pendidikan. Tujuan pendidikan terdiri dari dua yaitu tujuan pendidikan primer dan tujuan pendidikan sekunder. Tujuan pendidikan yaitu untuk dapat meningkatkan kualitas pengetahuan dan keterampilan,meningkatkan karakter warga negara, meningkatkan kualitas mental,dan meningkatkan struktur sosial masyarakat.

Maka secara keseluruhan dapat disimpulkan bahwa alasan yang mendasari diperlukannya analisis kebijakan yaitu untuk mengetahui segala bentuk kelayakan dan pembiayaan dari kebijakan yang diambil yang dianalisis melalui proses ilmiah dengan pendekatan saintifik.

Proses analisis kebijakan di Indonesia belum sepenuhnya dilaksanakan dengan maksimal. Kebijakan yang diambil banyak yang bersifat politis dan terkesan terburu-buru. Dari paparan yang disampaikan tersebut dapat disimpulkan bahwa pentingnya analisis kebijakan sebelum pengambilan keputusan dapat mempengaruhi terhadap keefektifan kebijakan tersebut.

Namun banyak yang disayangkan bahwa banyak kebijakan yang diambil di Indonesia tidak secara menyeluruh dilakukan proses analisis. Alhasil banyaknya kebijakan yang tidak pro aktif dan bersifat problem solving dihasilkan. Tidak dapat dipungkiri bahwa proses kebijakan memakan biaya yang besar sehingga banyak kebijakan yang akhirnya tidak terjalankan secara maksimal.

\section{Simpulan}

Analisis kebijakan merupakan sebuah ilmu sosial terapan yang menggunakan berbagai teknik dan metode dalam melahirkan informasi-informasi yang berhubungan dengan kebijakan. Analisis kebijakan ini sangat penting untuk dilaksanakan. Alasan yang mendasari diperlukannya analisis kebijakan yaitu untuk mengetahui segala bentuk kelayakan dan pembiayaan dari kebijakan yang diambil yang dianalisis melalui proses ilmiah dengan pendekatan saintifik. Dengan diketahuinya kelayakan sebuah kebijakan maka dapat dijadikan pertimbangan dalam melahirkan kebijakan tersebut dan dengan diketahuinya pembiayaan maka dapai disusun secara strategis dan efektif pengeluaran yang akan digunakan.

\section{Referensi}

Asmara, A. Y. (2016). Pentingnya Riset Kebijakan dalam Pembuatan Kebijakan Publik Unggul di Indonesia. JPSI (Journal of Public Sector Innovations), 1(1), 37-46.

Bawono, A. (2011). Kontribusi Religiusitas dalam Perilaku Pengambilan Keputusan Konsumsi. Muqtasid: Jurnal Ekonomi Dan Perbankan Syariah, 2(1), 115-133.

Dengah, J., Pioh, N., \& Kairupan, J. (2017). Evaluasi Kebijakan Penertiban Pedagang Kaki Lima Di Kota Manado. Jurnal Eksekutif, 2(2), 1-10.

Fernandes, R. (2018). Adaptasi Sekolah Terhadap Kebijakan Pendidikan Inklusif. Jurnal Socius: Journal of Sociology Research and Education, 4(2), 119-125.

Grindle, M. S. (2004). Good enough governance: poverty reduction and reform in developing countries. Governance, 17(4), 525-548.

Hanisy, A. (2013). Konsep dasar analisis kebijakan. Al Qodiri: Jurnal Pendidikan, Sosial dan Keagamaan, 4(1), 4863.

Hayati, E. (2014). Mewujudkan Good Governance dalam Pengelolaan Pemerintahan Daerah Guna Memperkuat Integrasi Nasional. Jurnal Serambi Edukasi, 2(2),1-10

Herdiana, D. (2018). Sosialisasi Kebijakan Publik: Pengertian dan Konsep Dasar. Jurnal Ilmiah Wawasan Insan Akademik, 1(3), 13-26. 
Ikbal, M. (2015). Evaluasi kebijakan penertiban ternak di kecamatan Parigi kabupaten Parigi Moutong. Katalogis, 3(10), 1-10.

Ismail, M. H., \& Sofwani, A. (2016). Konsep dan Kajian Teori Perumusan Kebijakan Publik. JRP (Jurnal Review Politik), 6(2), 195-224.

Kiwang, A. S., Pandie, D. B., \& Gana, F. (2015). Analisis Kebijakan dan Efektivitas Organisasi. JKAP (Jurnal Kebijakan dan Administrasi Publik), 19(1), 71-82.

Narita, R. M. (2012). Analisis kebijakan hutang. Accounting Analysis Journal, 1(2), 1-10.

Nugraha, M. T., Pandi, A., Supiana, S., \& Zaqiah, Q. Y. (2021). Formulasi Kebijakan Pendidikan di Pondok Pesantren Hidayatul Muhsinin Kubu Raya. Jurnal Pendidikan dan Konseling (JPDK), 3(1), 36-43.

Nurharjadmo, W. (2008). Evaluasi implementasi kebijakan pendidikan sistem ganda di sekolah kejuruan. Spirit Publik, 4(2), 215-228.

Prabowo, R. D., Manar, D. G., \& Adhi, S. (2014). Implementasi undang-undang keterbukaan informasi publik dalam upaya mewujudkan good governance (kajian tiga badan publik: Bappeda, Dpkad Dan Dinas Pendidikan Kota Semarang). Journal of Politic and Government Studies, 3(3), 187-195.

Pratiwi, S. N. (2016). Manajemen berbasis sekolah dalam meningkatkan Kualitas sekolah. EduTech: Jurnal Ilmu Pendidikan Dan Ilmu Sosial, 2(1), 1-10

Retnoningsih, Y. D., \& Marom, A. (2017). Analisis Kebijakan Penyelenggaraan Pendidikan Berbasis Uang Kuliah Tunggal Bagi Perguruan Tinggi Negeri Fakultas Ilmu Sosial Dan Ilmu Politik Universitas Diponegoro Semarang Jawa Tengah. Journal of Public Policy and Management Review, 6(2), 482-497.

Rusydi, I. (2014). Optimisme Pendidikan Madrasah Di Indonesia (Prospek Dan Tantangan). Risâlah, Jurnal Pendidikan dan Studi Islam, 1(1), 7-19.

Saifuddin, A. (2015). Eksistensi Kurikulum Pesantren dan Kebijakan Pendidikan. Jurnal Pendidikan Agama Islam (Journal of Islamic Education Studies), 3(1), 207-234.

Suti, M. (2011). Strategi peningkatan mutu di era otonomi pendidikan. Jurnal Medtek, 3(2), 1-6.

Syahwalan, M. (2019). Kebijakan Politik Keuangan Terhadap Pembangunan Negara dalam Sistem Ketatanegaraan Islam. Al Imarah: Jurnal Pemerintahan Dan Politik Islam, 4(1), 12-25.

Tressa, R. (2015). Analisis Kebijakan Penyelesaian Konflik Antardesa Di Kabupaten Sigi Provinsi Sulawesi Tengah. Journal Of Government (Kajian Manajemen Pemerintahan Dan Otonomi Daerah), 1(1), 61-90.

Wibowo, U. B. (2013). Intensitas Peran Aktor Kebijakan Dan Kekuatan Politis Dalam Perumusan Kebijakan Sertifikasi Pendidik. Jurnal Penelitian Ilmu Pendidikan, 6(1), 1-10. 